\title{
Some Aspects of Soil Acidification in Poland Based on Kódź Province
}

\author{
Monika Bojanowska ${ }^{1 *}$, Tadeusz Paszko ${ }^{1}$, \\ Izabella Jackowska ${ }^{1}$, Halina Lipińska \\ ${ }^{1}$ Department of Chemistry, University of Life Science, \\ Lublin, Poland \\ ${ }^{2}$ Department of Grassland and Landscape Forming, University of Life Science, \\ Lublin, Poland
}

Received: 10 March 2015

Accepted: 4 January 2016

\begin{abstract}
Our study shows the results of monitoring of soil acidification in Łódź Province and compares them to results for all of Poland. Łódź Province is ranked sixth in the country in terms of the highest emissions of particulate and gaseous pollutants, and represents Polish areas undergoing strong anthropogenic transformation. The substantial proportion of light soils and the considerable impact of human activity determine the susceptibility of the soils in the region to acidification, which deteriorates their quality. In terms of the proportion of very acidic soils, this is the second-highest region in Poland. The presented results clearly indicate that - despite the three-fold reduction of calcium fertilizer application in the last decade - the soil acidification status in Łódź Province and across Poland has improved slightly. It seems that a major cause of improvement in soil acidification is the substantial reduction of $\mathrm{SO}_{2}$ emissions in recent years. It has been shown that pollutant emissions have a negative impact on the content of available magnesium and, to a lesser extent, on the content of available potassium; in turn, it does not affect the level of available phosphorus.
\end{abstract}

Keywords: soil acidification, fertilization, air pollution, Łódź Province

\section{Introduction}

Łódź Province is situated in central Poland and covers an area of $18,219 \mathrm{~km}^{2}$, which accounts for $5.9 \%$ of the total area of the country [1]. It is divided into 24 counties, including three municipal counties (Łódź, Piotrków Trybunalski, and Skierniewice). The region comprises both agricultural areas (Łowicz and Łęczyca counties) and highly industrialized areas (Łódź agglomeration, Piotrków Trybunalski County). The province is the second

*e-mail: monika.bojanowska@up.lublin.pl largest energy producer in Poland. In terms of particulate and gas emissions, it occupies sixth place in the country [2].

The soils of Łódź Province are mainly represented by light soils (according to the WRB; Luvisols, Arenosols, and Podzols) accounting for ca. $85 \%$ of all soils in the region [3]. The best-quality soils are located in the northern part of the region (Kutno, Łowicz, Łęczyca counties). The substantial proportion of light soils and the great impact of human activity determine the susceptibility of the soils in the province to acidification, which is associated with reduced soil microbial activity and negative changes in physical properties [4]. Yet acidification induces the most sub- 
stantial changes in the chemical properties of soils, causes leaching of alkaline components and replacement thereof with hydrogen cations, and contributes to enhanced solubility of aluminum, manganese, and iron compounds as well as heavy metals $[5,6]$. Therefore, an increase in acidification decreases the bioavailability of plant nutrients [7] and causes a number of negative effects of the uptake of ions characteristic for acidic soil by plants $\left(\mathrm{Al}^{3+}\right.$ and heavy metal cations). The imbalance between acidic and alkaline ions is one of the most dangerous effects of chemical degradation of soils. Actual chemical soil degradation usually occurs when acidification resulting from the impact of environmental factors is combined with anthropopressure. This phenomenon is most enhanced in highly industrialized areas $[8,9,10]$.

The aim of our study was to evaluate the degree of soil acidification in Łódź Province and in Poland in the last decade, and to analyze the causes and effects of acidification.

\section{Materials and Methods}

The results of analyses of soil properties $(\mathrm{pH}, \mathrm{P}, \mathrm{K}$, $\mathrm{Mg}$ ) conducted by the Regional Chemical and Agricultural

a)

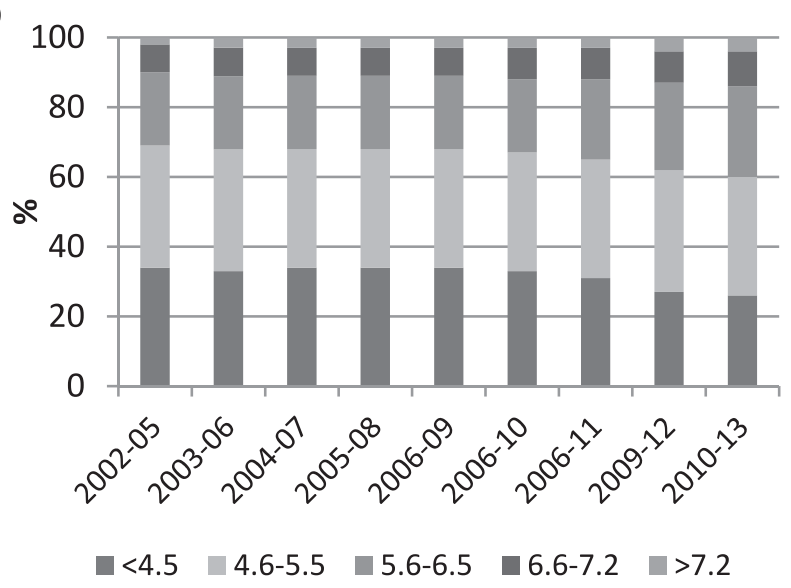

c)

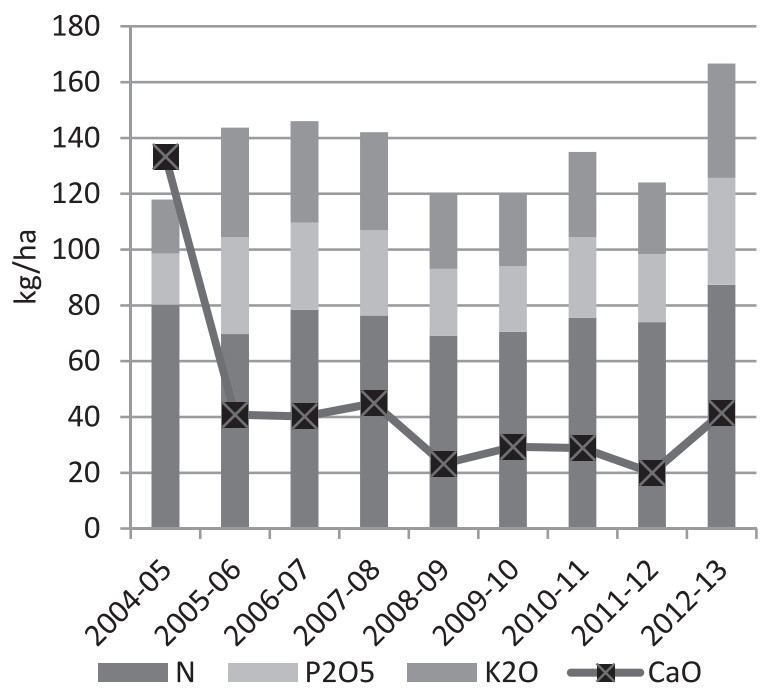

Station in Łódź in 2009-12 in counties of the region were used in this study. A total of 57,920 soil samples collected from the $0-20 \mathrm{~cm}$ layer of arable land in accordance with standard PN-R-04031:1997 [11] were analyzed in the laboratory of the Regional Chemical and Agricultural Station in Łódź to determine:

- $\mathrm{pH}$ in $1 \mathrm{~mol} \mathrm{KCl} \cdot \mathrm{dm}^{-3}$ - according to PN-ISO 10390:1997 [12].

- Content of available phosphorus and available potassium using the Egner-Riehm method (DL) - according to PN-R-04023:1996 [13] and PN-R04022:1996 [14].

- Content of available magnesium by AAS after extraction with $0.0125 \mathrm{~mol} \mathrm{CaCl} \cdot \mathrm{dm}^{-3}-$ according to PN-R-04020:1994 [15].

- $\mathrm{P}, \mathrm{K}$, and $\mathrm{Mg}$ content of organic soils after extraction in $0.5 \mathrm{~mol} \mathrm{HCl} \cdot \mathrm{dm}^{-3}$ - according to PN-R-04024 1997 [16].

Fertilizer consumption and pollutant emission data supplied by the Central Statistical Office in Poland were also used in the study [2].

Statistical analysis of the results presented in this paper was carried out using the Statgraphics Centurion XVI program. Pearson's correlation analysis was employed. b)

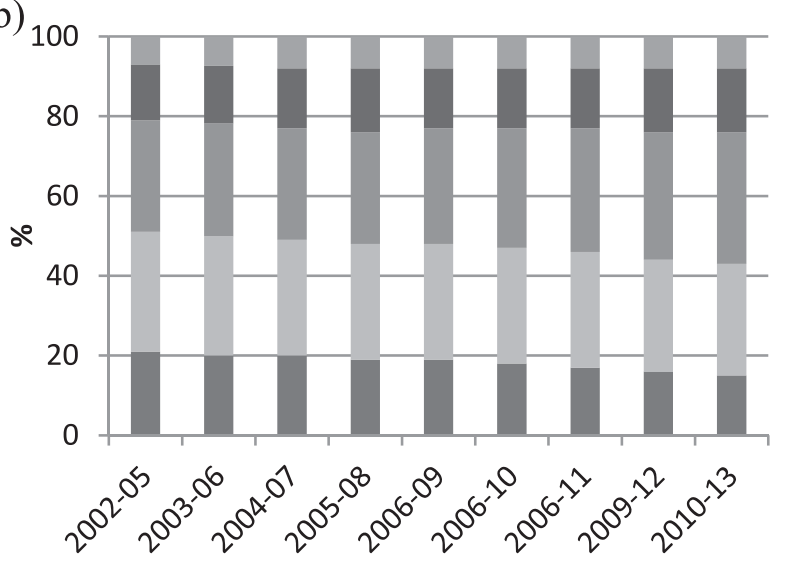

d)

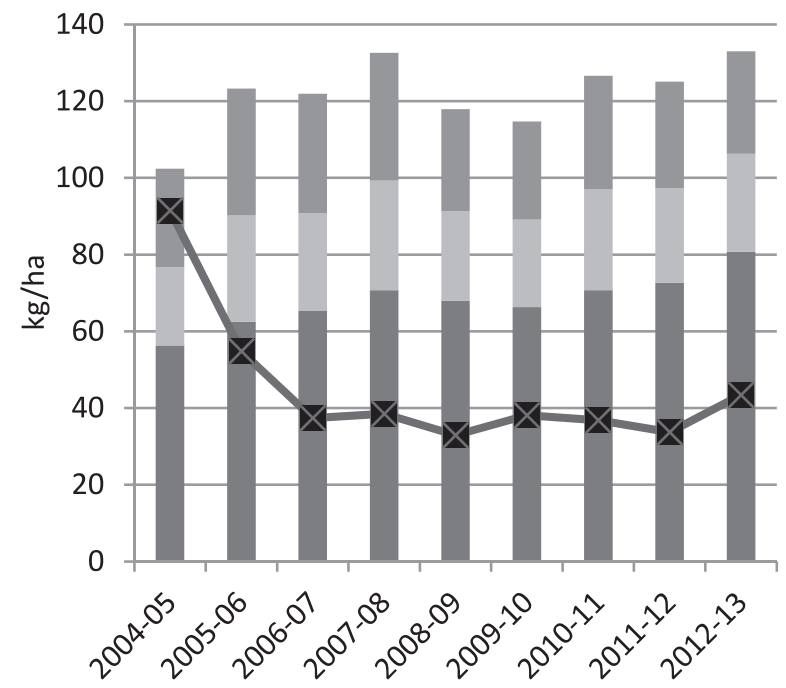

Fig. 1. Changes in soil acidification level and fertilizers use in the Łódź Province (a, c) and in Poland (b, d). 
Since this method may yield biased results when there is no normal distribution of the data, the correlations are not linear, or some results diverge from others; also, Spearman's correlation analysis, which is more resistant to these interferences, was used. Additionally, principal component analysis (PCA) was employed due to the frequent multicolinearity problem.

\section{Results and Discussion}

Changes in the Level of Soil Acidification and Fertilization in the Last Decade: Analyzing Central Statistical Office Data

Figs 1a, b presents changes in the level of soil acidification in 2002-13 in Łódź Province and Poland. It shows that the proportion of acidic soils in this province is significantly higher than the average values for the entire country. The proportion of very acidic and acidic soils in Łódź Province was 69\% in 2002-05 and decreased to 60\% in $2010-13$, whereas the values for Poland were $51 \%$ and $43 \%$, respectively [2].

The clear decreasing trend in the proportion of very acidic and acidic soils and the increasing proportion of soils with slightly acidic, neutral, and alkaline reaction have been evidently shown by monitoring conducted in 2006-10. These results are puzzling, as there has been a drastic decline in the application of calcium fertilizers in Poland since 2004 (Figs 1c, d) caused by the withdrawal of government subsidies in 2004 .

Furthermore, analysis of the use of nitrogen, phosphorus, and potassium fertilizers (NPK) per 1 ha of arable land in recent years indicates (Figs 1c, d) an increase in the application of nitrogen fertilizers. Therefore, the quantitative changes in the use of calcium and NPK fertilizers are not major factors contributing to the improvement of the soil acidification status in Poland. Comparison of data from 2008-12 shows that the consumption of calcium fertilizers in Łódź Province in this period was significantly lower than the average value for Poland, and the use of NPK exhibited a similar level. In the economic period 2012-13, the use of calcium fertilizers in the province reached the average level for Poland and the use of NPK exceeded the level.

The statistical analysis from individual provinces of Poland has shown a strong correlation between the use of NPK and calcium fertilizers. For instance, the value of Pearson's correlation coefficient $r$ for the correlation between the average consumption of calcium fertilizers and NPK per 1 ha of arable land in 2010-13 was 0.901 $(p<0.001)$, and the strongest correlation was found between the use of calcium and nitrogen fertilizers $(r=0.907, p<0.001)$. This results from the fact that provinces with greater plant production intensity are characterized by greater consumption of NPK and calcium fertilizers and greater efforts to maintain proper soil $\mathrm{pH}$. This relationship also explains the negative correlation of the percentage of very acidic soils not only with the consump- tion of calcium fertilizers ( $r=-0.830, p<0.001 ; 2010-13)$, which is obvious, but also with the use of NPK $(r=-0.801$, $p<0.001)$ and each of these fertilizers separately.

Soil acidification is caused by insufficient use of fertilizers that could maintain the soil $\mathrm{pH}$ within a desirable range $[17,18]$. In recent years, the use of agricultural lime decreased significantly in Poland from approximately $100 \mathrm{~kg} \mathrm{CaO} / \mathrm{ha}$ in 2000 to $34 \mathrm{~kg} \mathrm{CaO} / \mathrm{ha}$ in 2012 [19]. From that time lime use was reduced by $60 \%$, whereas nitrogen fertilization rates increased by ca. $45 \%$. The observed difference has important implications since it is usually assumed that an average of $60-110 \mathrm{~kg} \mathrm{CaCO}$ should be introduced to soil per every $100 \mathrm{~kg}$ of nitrogen fertilizer (ammonium sulfate, urea, ammonium nitrate, and derivatives) to decrease soil acidity [20]. Soil acidification is an issue with environmental and social implications, and liming treatments are needed to improve crop quality and prevent further degradation of the soil environment $[21,22]$.

However, it should be added here that the structure of calcium fertilizer sales has changed in Poland in recent years, i.e., the sale of the considerably more effective fertilizers produced from chalk has increased and the demand for limestone- and dolomite-derived fertilizers has declined. Therefore, it cannot be excluded that the use of even smaller amounts of more easily soluble chalk fertilizers characterized by higher contents of calcium has had a certain impact on the increase in soil $\mathrm{pH}$. Moreover, the structure of NPK use has changed in the last decade. Currently, instead of separate fertilizers mixed before application, multicomponent fertilizers are very often used, which contain calcium and/or magnesium and either do not acidify or minimally acidify soil. To some extent, this could explain the negative correlation between NPK consumption and the percentage of very acidic soils.

\section{The Level of Soil Acidification and Particulate and Gaseous Pollutants: Analyzing Central Statistical Office Data}

Changes in the level of the main air pollutants in Poland, i.e., sulfur dioxide, nitrogen oxides, and particulates, which potentially exert the greatest effect on soil pH, are presented in Fig. 2.

The data presented in Fig. 2a show a significant decline in $\mathrm{SO}_{2}$ emissions since 2007. This decrease is primarily caused by reduction of emissions of this combustionderived gas by the energy production and transformation sector, mainly by power plants, heat-and-power plants, and heat-only boiler stations. Noteworthy is the downward trend in the proportion of very acidic soils (Figs 1a, b) and the increase in the percentage of slightly acidic, neutral, and alkaline soils started in that period. This may indicate that $\mathrm{SO}_{2}$ emissions is currently the major anthropogenic factor determining soil acidification. Similar conclusions on the causes of soil acidification were presented by Filipek and Skowrońska [23]. Despite the significant reduction of gaseous pollutant emissions, in particular that of $\mathrm{SO}_{2}$ (average emissions in Poland in 2002 were $42 \mathrm{~kg}$ / 
ha and in $201026.6 \mathrm{~kg} / \mathrm{ha}$ [2]), this factor still enhances soil acidification pressure.

Emissions of nitrogen oxides (Fig. 2b) did not change substantially in the analyzed period (2003-12). The calculations of the anthropogenic-origin cation $\mathrm{H}^{+}$balance presented by Filipek and Skowrońska [23] have shown that hydrogen cation load introduced to the soil annually through emission of nitrogen oxides is approximately twice as low as that introduced by $\mathrm{SO}_{2}$ emissions, which have equaled the level of emissions in recent years. Hence, taking into account the results of the above authors' calculations and the simple fact that sulphur oxides are introduced into the soil with acidic precipitation as biprotonated acids and nitrogen oxides as monoprotonated acids, it can be assumed that soil acidification caused by emissions of $\mathrm{NO}_{\mathrm{x}}$ is currently two-fold lower than the acidification caused by $\mathrm{SO}_{2}$ emissions.

The total particulate emissions (Fig. 2c) in the analyzed period exhibited a minimal downward trend. A decline in the level of combustion-derived particulate emissions from the energy production and transformation sector as well as from industrial combustion processes and an increase in emission of particulates produced by road transport can be observed.

The statistical analysis of the results obtained in 200305 (the highest emissions and the lowest soil reaction) performed using Pearson's correlation coefficient $r$ and

a)

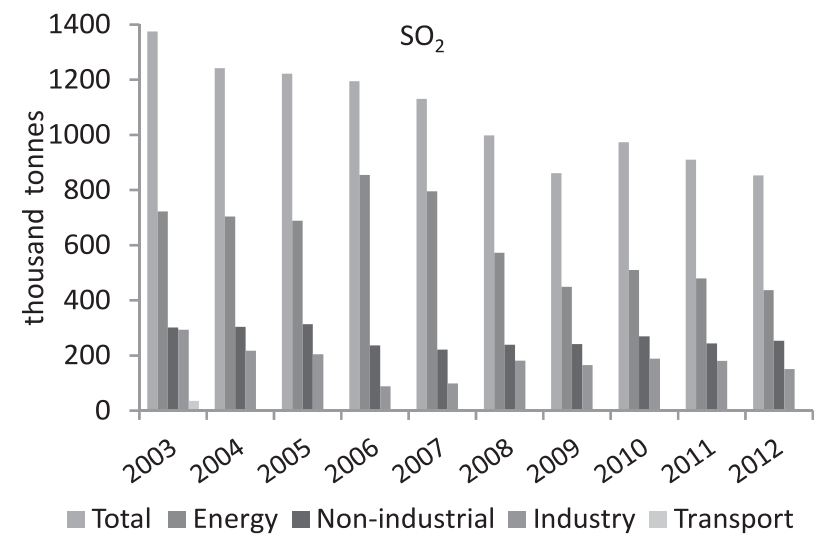

c)

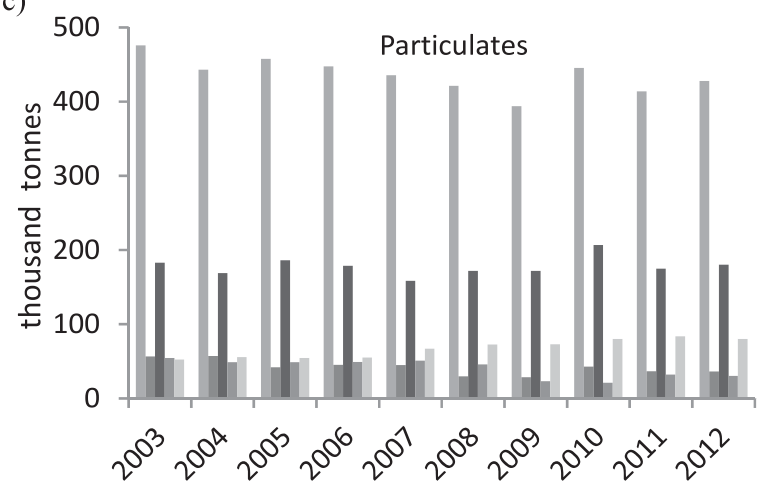

partial correlations $\rho$, and taking into account the total emissions of $\mathrm{SO}_{2}, \mathrm{NO}_{x}$, and particulates did not show significant correlations with soil reaction in Poland. Probably, the scale of the entire area of Poland and the provinces as single points is too high, since it reduces the effect of point emissions on acidification. The analysis demonstrated a strong correlation between $\mathrm{SO}_{2}$ and $\mathrm{NO}_{x}$ emissions $(r$ $=0.959, p<0.0001 ; \rho=0.833 p=0.0001)$ and a correlation with particulate emissions (e.g., for particulates and $\mathrm{SO}_{2}$ emissions $r=0.859$ and $p<0.0001$, but $\rho=0.011$ and $p=0.968$ ). The situation is very clearly presented (Fig. 2d) by the results of the Principal Component Analysis, which is one of the best methods for analysis in the presence of multicolinearity.

\section{Statistical Analysis of the Results from 57,920 Soil} Samples from Łódź Province

\section{Soils and Correlations Between their Reaction and Pollution Emissions}

The results of classification according to the agronomic categories of the soil samples collected in 2009-12 are presented in Fig. 3. Noteworthy are the samples of very light $(9.9 \%)$ and light $(62.2 \%)$ soils, which accounted for nearly three-fourths of all the analyzed samples. They were usually collected from Bełchatów, Opoczno, Pajęczno, and

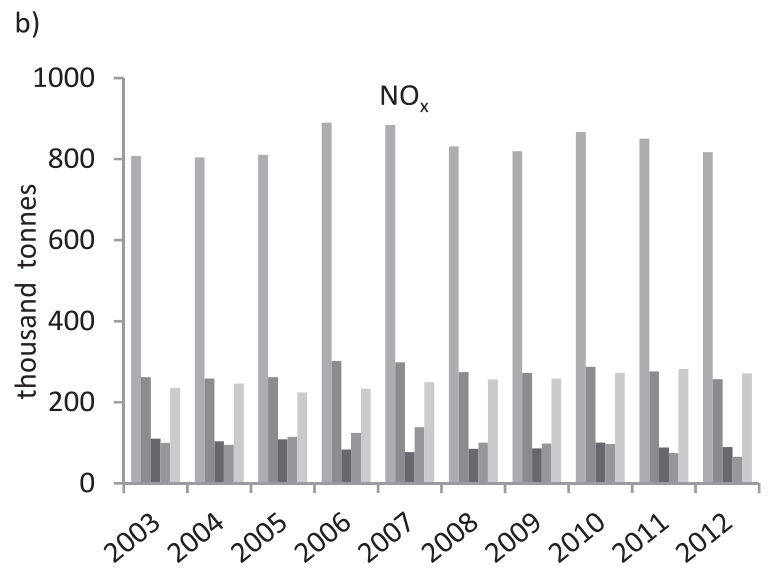

d)

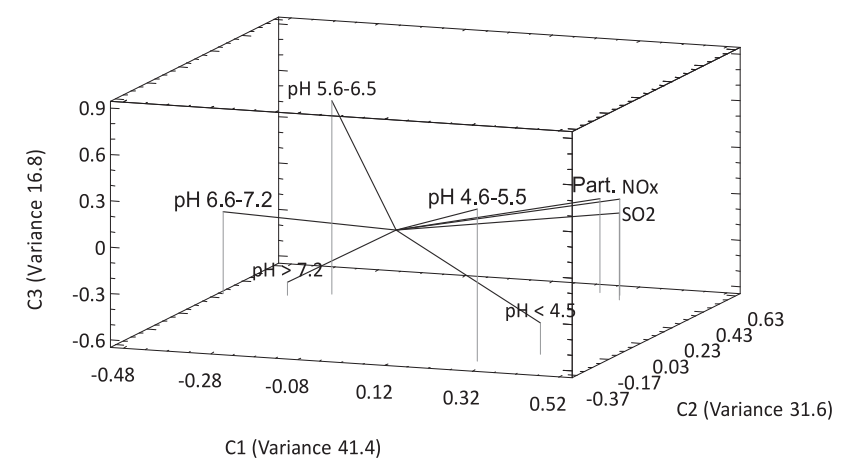

Fig. 2. Changes in levels of main air pollutants, i.e., sulfur dioxide (a), nitrogen oxides (b), particulates (c), and the relationship between soil $\mathrm{pH}$ and the pollutants according to PCA analysis (d). 


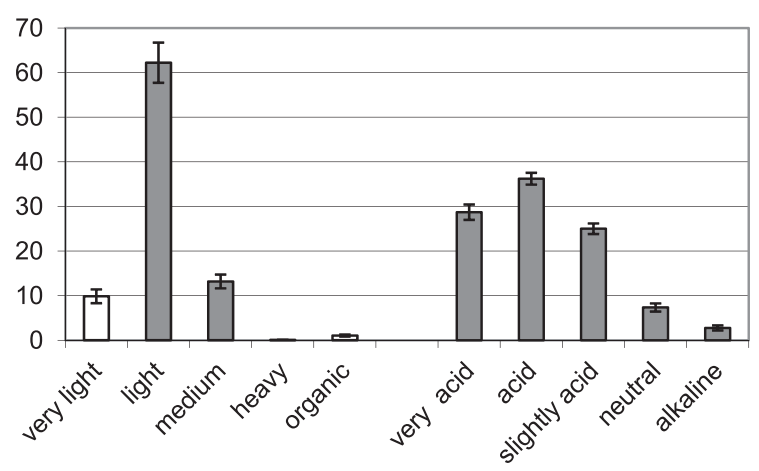

Fig. 3. Classification of soils according to the agronomic categories and $\mathrm{pH}$ in the Łódź Province.

Skierniewice counties. Brzeziny, Pabianice, Radomsko, and Zduńska Wola counties were characterized by the highest proportion of medium soils. Organic soils were mainly reported from Bełchatów and Pajęczno counties.

The values of Pearson's and Spearman's correlation coefficients (Table 1) showed unanimously that the very acidic and acidic soils are primarily very light, light, and organic soils. No statistically significant correlations were found between the number of samples collected from medium and heavy soils and their reaction.

The distribution of gaseous and particulate pollution in Łódź Province is not uniform. The greatest contribution to particulates and gaseous pollutant emissions was reported from Bełchatów County, with electricity and heat producers as the top emitters. The PGE Mining and Conventional Power S.A., Bełchatów Power Plant, emits 77\% of total point emissions in the province [24]. In the scale of the entire province, emissions from this power plant account for approx. $40 \%$ of particulate pollutant emissions and ca. $80 \%$ of all gas pollutants released into the air. The next largest emitter is Vedia Energia Łódź S.A., which is responsible for $7.9 \%$ of gas and particulate pollutants. The lowest levels of gas pollution were noted in Skierniewice, Poddębice, and Brzeziny counties. Besides Bełchatów County, the highest contribution to particulates pollution was noted in the cases of Pajeczno, Opoczno, and Wieruszów counties. The smallest amounts of particulates were emitted in Brzeziny, Piotrków, and Rawa counties.

The values of Pearson's correlation coefficients indicate a positive correlation between $\mathrm{SO}_{2}, \mathrm{NO}_{x}$, and particulate emissions and the proportion of very acidic soils. However, Spearman's rho correlation analysis did not show significant differences. Since $\mathrm{SO}_{2}, \mathrm{NO}_{x}$, and particulate emissions are highly correlated, the results obtained using principal component analysis are most reliable. PCA reveals a positive relationship between the $\mathrm{SO}_{2}, \mathrm{NO}_{\mathrm{x}}$, and particulate emissions and the proportion of very acidic soils in the province. In contrast, no such correlation can be found between acidic and slightly acidic soils, and there is a negative correlation in the case of neutral and alkaline soils. This is obvious, since very acidic soils are primarily very light soils with low sorption capacity, and emissions have the greatest impact on their acidification levels.

The effect of particulate emissions on soil reaction is a complex problem, as it depends on the chemical nature of particulate. As reported by Walczak [25], combustionderived particulates produced by the energy production and transformation sector have alkaline reaction and may cause alkalization of soils. Furthermore, calciumcontaining airborne particulates neutralize the acidifying effect of sulfur oxides (calcium sulfates (IV) and (VI) are poorly soluble compounds). However, the results of the statistical analysis presented in this study suggest an acidifying effect of particulates. Yet, it should be borne in mind that the strong colinearity between $\mathrm{SO}_{2}, \mathrm{NO}_{\mathrm{x}}$, and particulate emissions may yield biased results of a statistical analysis for a factor that exerts the smallest effect on soil $\mathrm{pH}$.

In summary, it seems that the contribution of gaseous pollutants to soil acidification is as dominant in Łódź Province as in all of Poland [26]. On the basis of the data on $\mathrm{SO}_{2}$ and $\mathrm{NO}_{x}$ emissions in 2012 [24], it was calculated (according to [27]) that acidification is caused in about $3 / 4$ by air pollutants. Another factor that is responsible for acidification is probably the use of physiologically acidic nitrogen fertilizers, which are dangerous when not connected with sufficient levels of calcium fertilizer [28].

\section{The Content of Available Macronutrients in Soils vs. Soil pH and Pollutant Emissions}

A high level of soil acidity is undesirable from the agricultural and environmental points of view. Nutrients, including potassium, magnesium, and calcium, are leached in an acidic environment. Other elements, in particular phosphorus, are converted into forms that are unavailable to plants [29]. On the other hand, mobile forms of cadmium, zinc, lead, and other metals are accumulated by plants and transferred to the food chain, which poses a threat for living organisms [30, 31]. The biological accumulation of toxic elements contributes to their negative effects on soil, plants, animals, and humans $[32,33]$.

Soils with very low or low content of available phosphorus represented $38 \%$ of the analyzed samples. High phosphorus content was noted for soils sampled from $15 \%$ of the analyzed areas, and very high content was found in $20 \%$ of the soils. The greatest numbers of soil samples characterized by very low and low phosphorus content (over half of the analyzed land) originated from Bełchatów, Poddębice, and Opoczno counties.

The analysis of the values of Pearson's and Spearman's coefficients as well as the PCA results clearly indicate that very light and light soils were characterized by very low $\left(r=0.556^{* * *}\right.$, rho $\left.=0.464^{* *}\right)$ or low $\left(r=0.711^{* * *}\right.$, rho $\left.=0.647^{* *}\right)$ phosphorus content. The analysis of correlations demonstrated a very strong positive correlation between the very low and low phosphorous contents and acidic and very acidic soil $\mathrm{pH}$ on the one hand. On the other hand, there was the same relationship between the very high abundance of this component and 
Table 1. Analysis of correlation (Pearson's $r$, top left, and Spearman's rho, bottom right) of the data from Łódź Province.

\begin{tabular}{|c|c|c|c|c|c|c|c|c|}
\hline & $\begin{array}{l}\mathrm{pH}<4.5 \\
\text { (very acid) }\end{array}$ & $\begin{array}{c}\mathrm{pH} 4.6- \\
5.5 \\
\text { (acid) }\end{array}$ & $\begin{array}{c}\mathrm{pH}<4.5-5.5 \\
\quad(\text { very acid } \\
\quad+\text { acid })\end{array}$ & $\begin{array}{c}\text { pH 5.6-6.5 } \\
\text { (slightly acid) }\end{array}$ & $\begin{array}{c}\mathrm{pH}>6.6 \\
\text { (neutral + } \\
\text { alkaline) }\end{array}$ & $\mathrm{SO}_{2}$ & $\mathrm{NO}_{x}$ & Particulates \\
\hline Very light & $\begin{array}{l}0.347 \\
0.378^{*}\end{array}$ & $\begin{array}{l}0.066 \\
0.014\end{array}$ & $\begin{array}{l}0.312 \\
0.319\end{array}$ & $\begin{array}{l}-0.230 \\
-0.194\end{array}$ & $\begin{array}{l}-0.283 \\
-0.089\end{array}$ & $\begin{array}{c}-0.103 \\
0.148\end{array}$ & $\begin{array}{l}-0107 \\
0.249\end{array}$ & $\begin{array}{c}-0.026 \\
0.231\end{array}$ \\
\hline Light & $\begin{array}{c}0.472^{* *} \\
0.322\end{array}$ & $\begin{array}{l}0.275 \\
0.129\end{array}$ & $\begin{array}{c}0.536 * * \\
0.210\end{array}$ & $\begin{array}{c}-0.554 * * * \\
-0.366\end{array}$ & $\begin{array}{c}-0.409 * * \\
-0.315\end{array}$ & $\begin{array}{c}0.200 \\
-0.116 \\
\end{array}$ & $\begin{array}{l}0.220 \\
0.266 \\
\end{array}$ & $\begin{array}{c}0.127 \\
-0.086 \\
\end{array}$ \\
\hline $\begin{array}{l}\text { Very light }+ \\
\text { light }\end{array}$ & $\begin{array}{l}0.613^{* * *} \\
0.618^{* * *}\end{array}$ & $\begin{array}{c}0.308 \\
-0.024\end{array}$ & $\begin{array}{c}0.667^{* * *} \\
0.348\end{array}$ & $\begin{array}{l}-0.656^{* * *} \\
-0.551^{* * *}\end{array}$ & $\begin{array}{c}-0.524^{* *} \\
-0.233\end{array}$ & $\begin{array}{c}0.171 \\
-0.029\end{array}$ & $\begin{array}{l}0.190 \\
0.116\end{array}$ & $\begin{array}{l}0.123 \\
0.113\end{array}$ \\
\hline Medium & $\begin{array}{c}-0.51 \\
-0.012\end{array}$ & $\begin{array}{l}0.361 \\
0.303\end{array}$ & $\begin{array}{l}0.178 \\
0.084\end{array}$ & $\begin{array}{l}0.018 \\
0.014\end{array}$ & $\begin{array}{l}-0.309 \\
-0.173\end{array}$ & $\begin{array}{l}-0.138 \\
-0.016\end{array}$ & $\begin{array}{l}-0.154 \\
-0.234\end{array}$ & $\begin{array}{l}-0.230 \\
-0.416\end{array}$ \\
\hline Organic & $\begin{array}{l}0.687^{* * * *} \\
0.623^{* * *}\end{array}$ & $\begin{array}{l}-0.010 \\
-0.125 \\
\end{array}$ & $\begin{array}{l}0.533^{* *} \\
0.533^{* *}\end{array}$ & $\begin{array}{c}-0.657^{* * *} \\
-0.769 \\
\end{array}$ & $\begin{array}{l}-0.283 \\
-0.099 \\
\end{array}$ & $\begin{array}{c}0.650^{* * * *} \\
0.174 \\
\end{array}$ & $\begin{array}{l}0.686 \\
0.214 \\
\end{array}$ & $\begin{array}{l}0.658 \\
0.213 \\
\end{array}$ \\
\hline $\mathrm{SO}_{2}$ & $\begin{array}{c}0.473^{* *} \\
0.020\end{array}$ & $\begin{array}{l}-0.174 \\
-0.210\end{array}$ & $\begin{array}{c}0.266 \\
-0.112\end{array}$ & $\begin{array}{c}-0.237 \\
0.077\end{array}$ & $\begin{array}{c}-0.213 \\
0.045\end{array}$ & & $\begin{array}{l}0.997^{\text {*** }} \\
0.865^{\text {*** }}\end{array}$ & $\begin{array}{l}0.966^{* * *} \\
0.784^{* * *}\end{array}$ \\
\hline $\mathrm{NO}_{\mathrm{x}}$ & $\begin{array}{c}0.487^{* *} \\
0.166\end{array}$ & $\begin{array}{l}-0.147 \\
-0.016 \\
\end{array}$ & $\begin{array}{l}0.293 \\
0.164\end{array}$ & $\begin{array}{l}-0.262 \\
-0.042 \\
\end{array}$ & $\begin{array}{l}-0.234 \\
-0.222 \\
\end{array}$ & $\begin{array}{l}0.997^{* * *} \\
0.865^{* * *}\end{array}$ & & $\begin{array}{l}0.973^{* * *} \\
0.914^{* * *}\end{array}$ \\
\hline Particulates & $\begin{array}{c}0.468^{* *} \\
0.234\end{array}$ & $\begin{array}{l}-0.194 \\
-0.188\end{array}$ & $\begin{array}{l}0.250 \\
0.149\end{array}$ & $\begin{array}{l}-0.227 \\
-0.130\end{array}$ & $\begin{array}{l}-0.189 \\
-0.053\end{array}$ & $\begin{array}{l}0.966^{* * *} \\
0.784^{* * *}\end{array}$ & $\begin{array}{l}0.973^{* * * *} \\
0.914^{* * *}\end{array}$ & \\
\hline $\mathrm{P}$ (very low) & $\begin{array}{l}0.454^{* *} \\
0.602^{* * *}\end{array}$ & $\begin{array}{c}-0.066 \\
0.113 \\
\end{array}$ & $\begin{array}{c}0.317 \\
0.462^{* *}\end{array}$ & $\begin{array}{l}-0.480 \\
-0.671 \\
\end{array}$ & $\begin{array}{c}-0.103 \\
0.046 \\
\end{array}$ & $\begin{array}{c}-0.608 \\
0.037\end{array}$ & $\begin{array}{c}-0.053 \\
0.050\end{array}$ & $\begin{array}{l}0.010 \\
0.078 \\
\end{array}$ \\
\hline P (low) & $\begin{array}{l}0.578^{* * *} \\
0.474^{* *}\end{array}$ & $\begin{array}{l}0.209 \\
0.273\end{array}$ & $\begin{array}{l}0.580^{* *} \\
0.440^{* *}\end{array}$ & $\begin{array}{l}-0.541^{* *} \\
-0.459^{* *}\end{array}$ & $\begin{array}{c}-0.470 \\
-0.462^{* *}\end{array}$ & $\begin{array}{c}0.365 \\
-0.060\end{array}$ & $\begin{array}{l}0.379 \\
0.049\end{array}$ & $\begin{array}{l}0.361 \\
0.031\end{array}$ \\
\hline $\mathrm{P}$ (medium) & $\begin{array}{l}0.110 \\
0.158 \\
\end{array}$ & $\begin{array}{l}0.572^{* * *} \\
0.534^{* *} \\
\end{array}$ & $\begin{array}{l}0.051 \\
0.373 \\
\end{array}$ & $\begin{array}{l}-0.109 \\
-0.065 \\
\end{array}$ & $\begin{array}{l}-0.584^{* *} \\
-0.051^{* *}\end{array}$ & $\begin{array}{l}-0.126 \\
-0.381 \\
\end{array}$ & $\begin{array}{l}-0.120 \\
-0.200 \\
\end{array}$ & $\begin{array}{l}-0.161 \\
-0.274 \\
\end{array}$ \\
\hline P (very high) & $\begin{array}{l}-0.375^{*} \\
-0.339 \\
\end{array}$ & $\begin{array}{l}0.029 \\
0.073 \\
\end{array}$ & $\begin{array}{l}-0.277 \\
-0.138 \\
\end{array}$ & $\begin{array}{c}0.395^{*} \\
0.306 \\
\end{array}$ & $\begin{array}{l}0.130 \\
0.023 \\
\end{array}$ & $\begin{array}{c}-0.183 \\
0.126 \\
\end{array}$ & $\begin{array}{l}-0.204 \\
-0.038 \\
\end{array}$ & $\begin{array}{l}-0.197 \\
-0.084 \\
\end{array}$ \\
\hline K (very low) & $\begin{array}{c}0.54^{* *} \\
0.496^{* *}\end{array}$ & $\begin{array}{l}-0.130 \\
-0.226 \\
\end{array}$ & $\begin{array}{c}0.345 \\
0.490^{* *}\end{array}$ & $\begin{array}{l}-0.408 \\
-0.434 \\
\end{array}$ & $\begin{array}{l}-0.182 \\
-0.084 \\
\end{array}$ & $\begin{array}{c}0.492^{* *} \\
0.090\end{array}$ & $\begin{array}{c}0.494^{* *} \\
0.259 \\
\end{array}$ & $\begin{array}{l}0.534^{* *} \\
0.443^{* *}\end{array}$ \\
\hline K (low) & $\begin{array}{l}0.300 \\
0.249 \\
\end{array}$ & $\begin{array}{l}-0.128 \\
-0.181 \\
\end{array}$ & $\begin{array}{c}0.157 \\
-0.113 \\
\end{array}$ & $\begin{array}{l}-0.245 \\
-0.127 \\
\end{array}$ & $\begin{array}{c}-0.071 \\
0.135 \\
\end{array}$ & $\begin{array}{c}-0.006 \\
0.000 \\
\end{array}$ & $\begin{array}{c}-0.017 \\
0.246 \\
\end{array}$ & $\begin{array}{l}-0.046 \\
-0.176 \\
\end{array}$ \\
\hline $\mathrm{K}$ (medium) & $\begin{array}{c}-0.587 \\
-0.582^{* * *} \\
\end{array}$ & $\begin{array}{c}0.3162 \\
0.559 \\
\end{array}$ & $\begin{array}{l}-0.269 \\
-0.158 \\
\end{array}$ & $\begin{array}{l}0.536^{* *} \\
0.541^{* *}\end{array}$ & $\begin{array}{l}-0.100 \\
-0.267 \\
\end{array}$ & $\begin{array}{l}-0.358 \\
-0.138 \\
\end{array}$ & $\begin{array}{c}-0.343 \\
0.037 \\
\end{array}$ & $\begin{array}{l}-0.294 \\
-0.062 \\
\end{array}$ \\
\hline $\begin{array}{l}\text { K (high }+ \\
\text { very high) }\end{array}$ & $\begin{array}{l}-0.602^{* * *} \\
-0.501^{* *}\end{array}$ & $\begin{array}{l}-0.0231 \\
0.0201^{* *}\end{array}$ & $\begin{array}{c}-0.486 \\
-0.406^{*} \\
\end{array}$ & $\begin{array}{l}0.401 \\
0.310 \\
\end{array}$ & $\begin{array}{c}0.9646^{* *} \\
0.246\end{array}$ & $\begin{array}{l}-0.287 \\
-0.130 \\
\end{array}$ & $\begin{array}{l}-0.290 \\
-0.201 \\
\end{array}$ & $\begin{array}{c}-0.347 \\
-0.414^{*} \\
\end{array}$ \\
\hline $\begin{array}{c}\mathrm{Mg} \text { (very } \\
\text { low) }\end{array}$ & $\begin{array}{l}0.731^{* * *} \\
0.743^{* * *}\end{array}$ & $\begin{array}{c}-0.004 \\
0.092\end{array}$ & $\begin{array}{l}0.571 * * * \\
0.673 * * *\end{array}$ & $\begin{array}{l}-0.575^{* * *} \\
-0.662^{* * *}\end{array}$ & $\begin{array}{l}-0.405 \\
-0.432\end{array}$ & $\begin{array}{c}0.612^{* * *} \\
0.239\end{array}$ & $\begin{array}{c}0.639^{* * *} \\
0.427^{*}\end{array}$ & $\begin{array}{c}0.692^{* * *} \\
0.433^{*}\end{array}$ \\
\hline Mg (low) & $\begin{array}{l}-0.08 \\
0.188 \\
\end{array}$ & $\begin{array}{c}-0.476^{* *} \\
-0.373 \\
\end{array}$ & $\begin{array}{l}-0.294 \\
-0.021 \\
\end{array}$ & $\begin{array}{l}0.245 \\
0.045 \\
\end{array}$ & $\begin{array}{l}0.296 \\
0.256 \\
\end{array}$ & $\begin{array}{c}-0.143 \\
0.061 \\
\end{array}$ & $\begin{array}{c}-0.155 \\
0.073 \\
\end{array}$ & $\begin{array}{c}-0.098 \\
0.066 \\
\end{array}$ \\
\hline $\begin{array}{l}\mathrm{Mg}(\mathrm{me}- \\
\text { dium) }\end{array}$ & $\begin{array}{c}-0.489^{* *} \\
-0.359 \\
\end{array}$ & $\begin{array}{l}-0.098 \\
-0.057 \\
\end{array}$ & $\begin{array}{c}-0.443 * * \\
-0.430 *\end{array}$ & $\begin{array}{l}0.340 \\
0.254 \\
\end{array}$ & $\begin{array}{c}0.433^{* *} \\
0.377 \\
\end{array}$ & $\begin{array}{c}-0.550^{* * *} \\
-0.310 \\
\end{array}$ & $\begin{array}{c}-0.555^{* * * *} \\
-0.392^{*} \\
\end{array}$ & $\begin{array}{l}-0.606^{* * *} \\
-0.459^{* *}\end{array}$ \\
\hline $\begin{array}{l}\text { Mg (very } \\
\text { high) }\end{array}$ & $\begin{array}{l}-0.325 \\
-0.414\end{array}$ & $\begin{array}{l}0.152 \\
0.120\end{array}$ & $\begin{array}{l}-0.163 \\
-0.307\end{array}$ & $\begin{array}{l}0.093 \\
0.163\end{array}$ & $\begin{array}{l}0.139 \\
0.156\end{array}$ & $\begin{array}{l}-0.140 \\
-0.108\end{array}$ & $\begin{array}{l}-0.157 \\
-0.342\end{array}$ & $\begin{array}{l}-0.218 \\
-0.340\end{array}$ \\
\hline
\end{tabular}

$* p<0.1, * * p<0.05, * * * p<0.01$.

the neutral and alkaline soil reaction (Table 1, Figs. 4a, b). No statistically significant correlations were found between $\mathrm{SO}_{2}, \mathrm{NO}_{\mathrm{x}}$, and particulate emissions and the levels of available phosphorus in soils.

In a majority of counties of Łódź Province, threefourths of the investigated soils were characterized by deficiencies in available potassium. Soils with very low and low contents of available potassium represented $59 \%$ of the investigated samples. As much as $70 \%$ of soils with very low or low contents were reported in Poddębice and Opoczno counties, and nearly $50 \%$ of soils with the lowest abundance of this nutrient originated from Kutno County.

The statistical analysis of the results did not reveal significant correlations between the soil agronomic category and the content of available potassium. PCA and Pearson's correlation coefficients (Table 1, Figs. 4c, d) indicate a positive correlation between the very low contents of this element and the proportion of very acidic soils, and be- 
tween the high and very high contents of available potassium and soils and slightly acidic, neutral, or alkaline $\mathrm{pH}$. The PCA results and Pearson's correlation coefficients indicate a positive correlation between $\mathrm{SO}_{2}, \mathrm{NO}_{x}$, and particulate emissions and the proportion of soils with very low levels of available potassium.

The soils with very low and low contents of available magnesium represented over $33 \%$ of the analyzed samples. Among the soils from all the counties of Łódź Province, over $20 \%$ exhibited very low and low levels of the nutrient. Over one-third of magnesium-poorest soils were found in Opoczno, Łask, Tomaszów, Piotrków, Sieradz, Rawa, Radomsko, and Poddębice counties.

The statistical analysis of the results demonstrated a positive correlation between the low levels of available magnesium and the proportion of very light and light $\left(r=0.446^{* *}, r h o=0.571^{* *}\right)$ and organic $\left(r=0.615^{* * *}\right.$, $\left.r h o=0.494^{* *}\right)$ soils, and soils with very acidic $\mathrm{pH}$ (Table 1, Fig. 4e,f). Additionally, the smallest percentage of available magnesium was noted in areas characterized by the highest $\mathrm{SO}_{2}, \mathrm{NO}_{2}$, and particulate emissions.

\section{Conclusions}

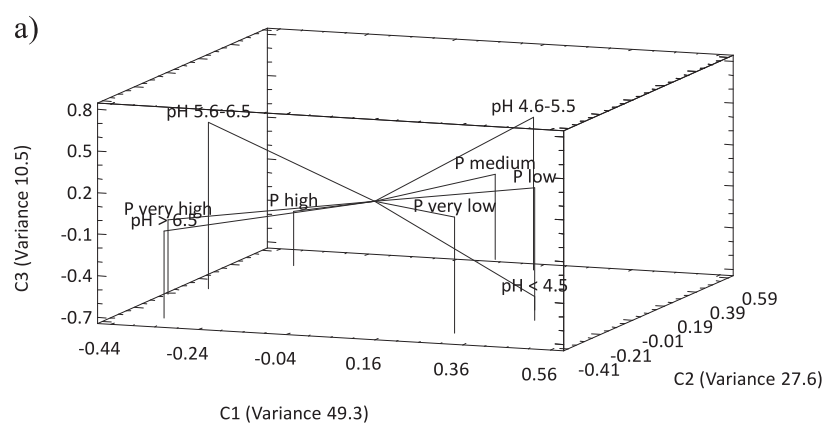

c)

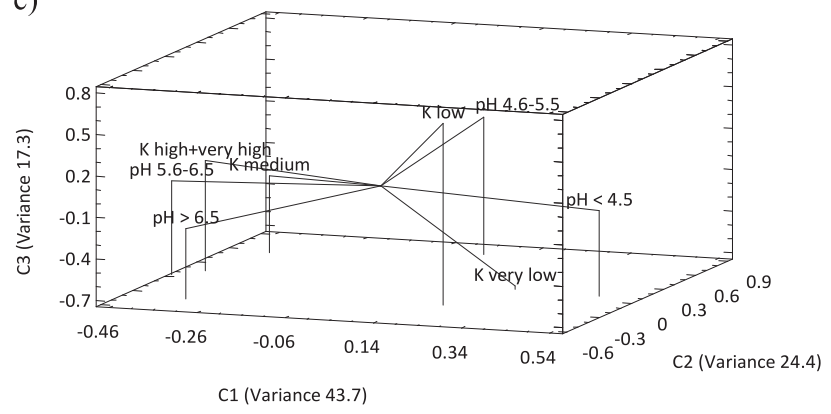

e)

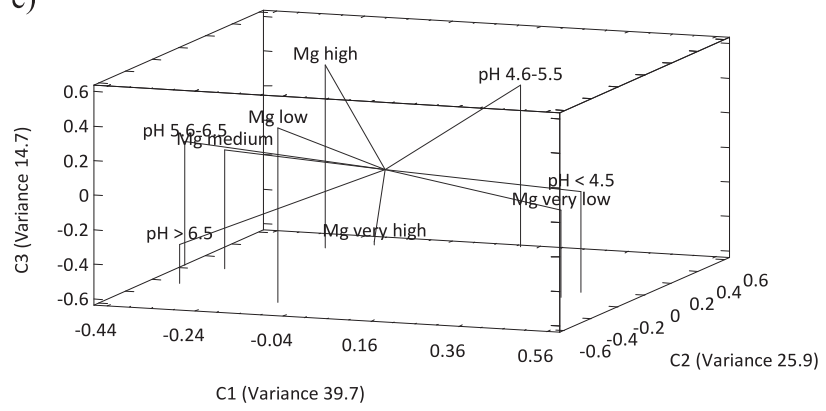

Soil surveys carried out in Łódź Province in 2009-12 revealed that most agricultural land was characterized by very high and high acidity, which does not create a supportive environment for optimal growth and development of crop plants. The $\mathrm{pH}$ of soil should be modified to promote transformation of mineral nutrients (mobilization and immobilization) and circulation of minerals in the environment, and to prevent the toxic accumulation of heavy metals.

The presented results, some of which are puzzling to the authors of the study, have demonstrated that such soil properties as $\mathrm{pH}$ and nutrient content are strongly dependent on anthropogenic factors. Changes in their intensity have a significant effect on soil $\mathrm{pH}$.

1. The results clearly demonstrate that the soil acidification status has improved slightly despite the three-fold reduction of the use of calcium fertilizers in Poland in the last decade.

2. It can be assumed that this is related to the improved quality of the calcium fertilizers used in Poland and the increasing application of modern multicomponent fertilizers, resulting in lack of or minimal soil

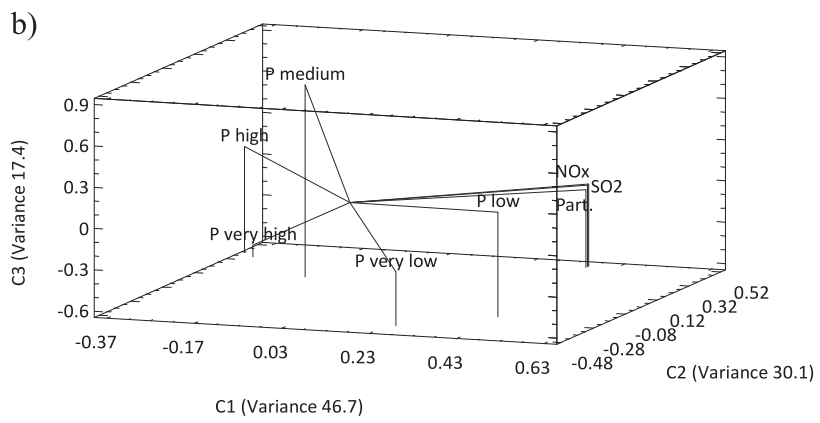

d)

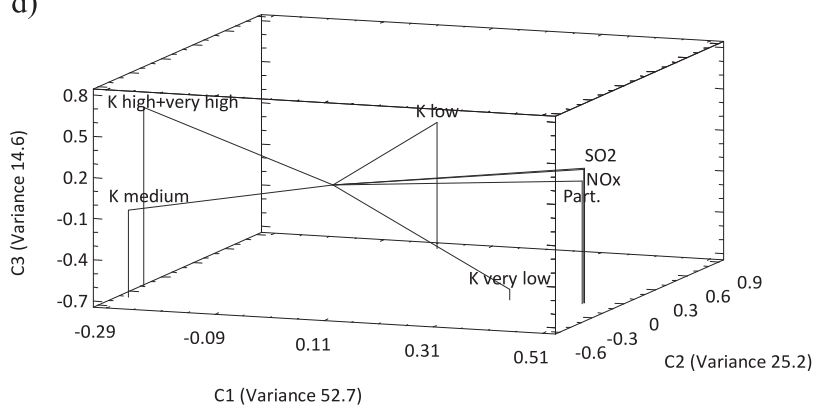

f)

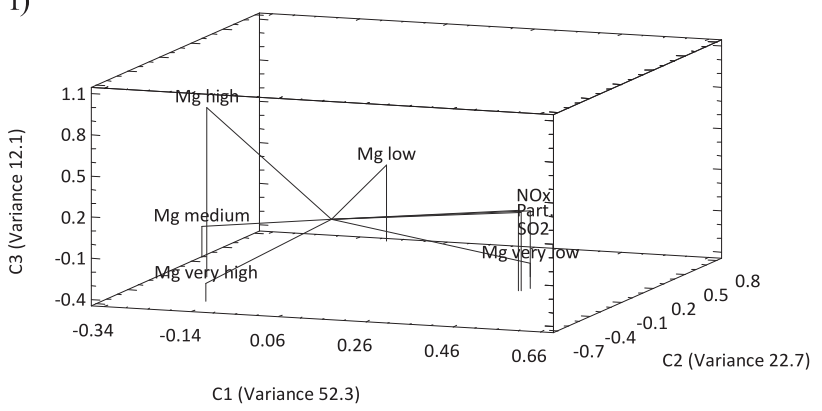

Fig. 4. PCA analysis of dependencies between the content of macronutrients in soils of Łódź Province and soil $\mathrm{pH}^{2}$ and emissions of $\mathrm{SO}_{2}$, $\mathrm{NO}_{\mathrm{x}}$, and particulates (denoted as Part.) from the point sources. 
acidification. This hypothesis, however, requires further investigation. The results of the statistical analysis even suggest a statistically significant positive correlation between soil $\mathrm{pH}$ and the NPK dose.

3. The analysis of the results indicates that $\mathrm{SO}_{2}$ emissions influence soil $\mathrm{pH}$ most strongly, and that the effect of $\mathrm{NO}_{\mathrm{x}}$ emissions was two-fold lower. The limitation of $\mathrm{SO}_{2}$ emissions in recent years seems to be a direct cause of the improved soil acidification status.

4. Analysis of the soil samples collected in Łódź Province demonstrated the same relationships of the effect of anthropogenic factors on soil reaction as in the analysis of Central Statistical Office data for all of Poland. A significant effect of the amount of gases and particulates emitted in this province on soil reaction and soil nutrient content has been demonstrated.

5. Based on the results obtained for Łodź Province, it was shown that emissions $\left(\mathrm{SO}_{2}, \mathrm{NO}_{x}\right.$ and particulates from point sources) has a relatively strong negative impact on the content of available magnesium in soil, a lesser effect on the content of available potassium, and no impact on the content of available phosphorus.

\section{References}

1. http://lodz.stat.gov.pl/gfx/lodz/userfiles/_public/pliki/ foldery/201203_f_woj_lodzkie_201pdf.

2. http://stat.gov.pl/

3. MOCEK A. (ed). Soil Science. Gleboznawstwo. PWN Warsaw, 2015 [In Polish].

4. FUJII K., FUNAKAWA S., KOSAKI T. Soil Acidification: Natural Processes and Human Impact. Pedologist 55, 415, 2012.

5. DEGRYSE F., VLASSAK V., SMOLDERS E., MERCKX R. Mobilization of cadmium upon acidification of agricultural soils: column study and field modeling. Eur. J. Soil Sci. 58, 152, 2007.

6. KIM A.Y, KIM Y.J, KO M.S., KIM K.W. Acid rain impact on phytoavailability of heavy metals in soils. Geosystem Engineering 13 (4), 133, 2010.

7. BOLAN N.S., ADRIANO D.C., CURTIN D. Soil acidification and liming interactions with nutrient and heavy metal transformation and bioavailability. Adv. Agron. 78, $215,2003$.

8. GUO Y.B., FENG H., CHEN CH., JIA CH.J., XIONG F., LU Y. P. Heavy metal concentrations in soil and agricultural products near an industrial district. Pol. J. Environ. Stud. 22 (5), 1357, 2013.

9. ADAMCZYK-SZABELA D. Assessing heavy metal content in soils surrounding electroplating plants. Pol. J. Environ. Stud. 22 (4), 1247, 2013.

10. JANKIEWICZ B., ADAMCZYK D. Assessing heavy metal content in soils surrounding a power plant. Pol. J. Environ. Stud. 19 (4), 849, 2010.

11. PN-R-04031:1997. Chemical-agricultural analysis of soil. Sampling.

12. PN-ISO 10390:1997. The quality of the soil. Determination of $\mathrm{pH}$.

13. PN-R-04023:1996. Chemical-agricultural analysis of soil. Determination of available phosphorus in mineral soils.

14. PN-R-04022:1996/ Az1:2002. Chemical-agricultural analysis of soil. Determination of available potassium in mineral soils.

15. PN-R-04020:1994/Az1:2004. Chemical-agricultural analysis of soil. Determination of available magnesium.

16. PN-R-04024:1997. Chemical-agricultural analysis of soil. Determination of the content of available phosphorus, potassium, magnesium, and manganese organic soils.

17. JADCZYSZYN T. Fertilization needs of arable land in Poland. Conference Materials "Liming of the soil - a challenge for the Polish economy". Puławy, 45, 2012 [In Polish].

18. HOŁUBOWICZ-KLIZA G. Soil liming in Poland. IUNG Puławy, 2006 [In Polish].

19. PIWOWAR A. Consumption of lime fertilizers in Poland and the demand for soil liming. Technika Rolnicza Ogrodnicza Leśna 1, 24, 2015 [in Polish].

20. GRZEBISZ W., DIATTA J.B., SZCZEPANIAK W. Production and ecological background of arable soil liming. Nawozy i Nawożenie (Fertilizers and Fertilization) 2, 69, 2006 [In Polish].

21. JASKULSKA I., JASKULSKI D., KOBIERSKI M. Effect of liming on the change of some agrochemical soil properties in a long-term fertilization experiment. Plant Soil Environ. 60 (4), 146, 2014.

22. JACKOWSKA I., KACZOR A. Comprehensive solution of the problem of acidification of soils in the province Silesia caused by anthropogenic transformations. Acta Agrophys. 186, 1, 2010.

23. FILIPEK T., SKOWROŃSKA M. Current dominant causes and effects of acidification of soils under agricultural use in Poland. Acta Agrophys. 20 (2), 283, 2013 [In Polish].

24. http://www.wios.lodz.pl/Raport_o_stanie_srodowiska_w wojewodztwie_lodzkim_w_2012_r,12,7

25. WALCZAK B. Road dust as a potential threat to urban ecosystems on the example of Zielona Góra. Uniwersytet Zielonogórski, Wydział Inżynierii Lądowej i Środowiska, Zielona Góra, 2008 [In Polish].

26. KACZOR A. BRODOWSKA M.S. Effect of sulphur dioxide and nitrogen oxides emission on soil acidification in Poland. Proc ECOpole 2 (1), 191, 2008 [In Polish].

27. FILIPEK T. (ed.). Basics and effects of chemicals use in agro-ecosystems. Wyd. UP Lublin, 2002 [In Polish].

28. BRODOWSKA M.S., KACZOR A. Impact of nitrogen fertilization on soil acidification. Proc ECOpole 1 (1/2), 97, 2007 [In Polish].

29. CH'NG H.Y., AHMED O.H.AB. MAJIDE N.M. Improving phosphorus availability in an acid soil using organic amendments produced from agroindustrial wastes. Sci. World J. 2014, 1, 2014 (Article ID 506356) http://dx.doi. org $/ 10.1155 / 2014 / 506356$

30. LACATSU R., LACATSU A.R. Vegetable and fruits quality within heavy metals polluted areas in Romania. Carpath. J. Earth Env. 3 (2), 115, 2008.

31. TOMAS J., ARVAY J., TOTH T. Heavy metals in productive parts of agricultural plants. J. Microbiol. Biotech. Food Sci. 1, 819, 2012.

32. IARC MONOGRAPHS ON THE EVALUATION OF CARCINOGENIC RISKS TO HUMANS: Cadmium and Cadmium Compounds, 100C, 121, 2012.

33. GUERRA F., TREVIZAM A.R., MURAOKA T., MARCANTE N.C., CANNIATTI-BRAZACA S.G. Heavy metals in vegetables and potential risk for human health. Sci. Agric. 69 (1), 54, 2012. 